\title{
KERKELIJKE ALARMKRETEN OVER KINDERVERSMACHTING DOOR HET BIJ ZICH IN BED NEMEN VAN ZUIGELINGEN (16de-18de EEUW)
}

\section{H. STORME ${ }^{\circ}$}

In het najaar van 1986 verscheen van de hand van Chris Vandenbroeke een belangwekkend boek over Vrijen en trouwen van de Middeleeuwen tot heden, waarin voor een groot publiek een breed opgezette, op wetenschappelijke leest geschoeide en tegelijk vlot leesbare synthese gebracht wordt van de bevindingen van de historische demografie en van de gezinsgeschiedenis in binnen- en buitenland ${ }^{1}$. Ik wil mij in dit artikel geenszins wagen aan een globale bespreking van deze boeiende publikatie. Wel zou ik enkele kritische bedenkingen willen formuleren i.v.m. een passage uit het negende hoofdstuk over "levenskansen van zuigelingen" waarin beweerd wordt dat onze voorouders tot en met de $18 \mathrm{e}$ eeuw vrij courant naar het ultieme en naar ons aanvoelen barbaarse middel van kindermoord hebben gegrepen om hun vruchtbaarheid a posteriori te corrigeren en de kinderlast binnen de perken te houden. Het overlijden van een baby zou dan door de betrokken ouder(s) meestal als een spijtig ongeval zijn voorgesteld, te wijten aan verstikking in het ouderlijk bed. Het is in die zin dat Chris Vandenbroeke, daarin

- Aspirant N.F.W.O.,K.U. Leuven, departement geschiedenis, Blijde Inkomststraat 21,3000 Leuven

1. C. VANDENBROEKE, Vrijen en trouwen van de Middeleeuwen tot heden. Seks, liefde en huwelijk in historisch perspectief, Brussel-Amsterdam, 1986. Voor een kritische evaluatie van het cuvre van Chris Vandenbroeke, geschreven voor het verschijnen van voornoemd boek, zie : W. VERRELST, "Chris Vandenbroeke : kijk op verleden en toekomst van het Vlaamse volk”, in : Ons Erfdeel 30(1987), p. 9-17. 
wellicht geïnspireerd door Jean-Louis Flandrin ${ }^{2}$ e.a., kerkelijke verbodsbepalingen om heel jonge kinderen bij zich in bed te nemen meent te kunnen interpreteren. Het is vooral de interpretatie van een laat-16e-eeuwse Franse kerkelijke bron, die als bewijsstuk geciteerd wordt, die mij de wenkbrauwen deed fronsen, en die bij nader toezien overhaast en wetenschappelijk onverantwoord blijkt te zijn. Voor de Vlaamse regio heb ik een aantal gelijkaardige teksten uit de $17 \mathrm{e}$ en de $18 \mathrm{e}$ eeuw bijeengebracht, waaruit al evenmin valt af te leiden dat kerkelijke gezagsdragers zouden gereageerd hebben tegen als ongeval gecamoufleerde kindermoorden, of zelfs maar op de hoogte zouden zijn geweest van het bestaan van dergelijke praktijken. Vanzelfsprekend zal in de loop van het betoog ook gerefereerd worden naar andere historici die deze problematiek al eerder hebben aangesneden ${ }^{3}$.

Maar om niet in het luchtledige te redeneren, en om de geïnteresseerde lezer die Vrijen en trouwen niet binnen handbereik heeft van dienst te zijn, is het wellicht nuttig om de bedoelde passus in extenso te citeren :

"Bij tijd en wijle stak men overigens een handje toe om de kinderlast wat af te remmen, zij het dan op een nogal primitieve manier en met middelen die ons heden eerder barbaars

2. J.-L. FLANDRIN, "L'attitude à l'égard du petit enfant et les conduites sexuelles. Structures anciennes et évolution", voor het eerst verschenen in Annales de démographie historique van 1973 (p. 143-210) en later hernomen in : J.-L. FLANDRIN, Le sexe et l'Occident. Evolution des attitudes et des comportements, Parijs, 1981, p. 151-216. In het vervolg wordt steeds naar deze laatste uitgave verwezen. Wat het bij zich in bed nemen van kinderen betreft, leze men vooral het kapitteltje over "L'oppiession et la suffocation d'enfant" op p. 172-5.

3. Voor een recent literatuuroverzicht i.v.m. het fenomeen kindermoord in het algemeen, verwijzen we graag naar P. FERNANDEZ, "Het verschijnsel kindermoord in de Nederlanden (XIVde-XVde eeuw)", in : W. PREVENIER, R. VAN UYTVEN, E. VAN CAUWENBERGHE (ed.), Sociale structuren en topografie van armoede en rijkdom in de $14 \mathrm{e}$ en $15 \mathrm{e}$ eeuw. Methodologische aspecten en resultaten van recent onderzoek. Handelingen van het colloquium gehouden te Gent op 24 mei 1985, (Studia Historica Gandensia, 267), Gent, 1986, p. 111-33. Andere studies i.v.m. de Nieuwe Tijd die in dit overzicht niet zijn opgenomen zijn o.m. : J. GELIS, M. LAGET, M.-F. MOREL, Entrer dans la vie. Naissances et enfances dans la France traditionnelle, (Collection Archives, 72), Parijs, 1978 (zie vooral p. 122-4) ; S. FABER, "Kindermoord, in het bijzonder in de achttiende eeuw te Amsterdam", in : Bijdragen en Mededelingen betreffende de Geschiedenis der Nederlanden 93 (1978), p. 224-40 en R. LABOUTTE, "L'infanticide dans l'est de la Belgique aux XVIIIe-XIXe siècles : une réalité", in : Annales de démographie historique, 1983, p. 163-92. 
overkomen. Kindermoord, nochtans courant tijdens de Oudheid en de Middeleeuwen toegepast, getuigt stellig van een niet al te hoog beschavingspeil ; hetzelfde dient gezegd, ook al komt het reeds wat "humaner" over, van gecamoufleerde moorden door pasgeboren baby's bij zich in bed te nemen en ze op die manier te laten verstikken. Zogezegd stond men dan 's morgens voor en spijtige verrassing ! Kerkelijk verordeningen hebben ontelbare keren tegen dergelijke gebruiken uitgehaald, zeer goed wetend welke risico's ze inhielden en beseffend dat het in werkelijkheid om een verkapte vorm van kindermoord ging. Een getuigenis van Benedicit, bisschop van Lyon in de 16de eeuw, laat er geen twijfel over bestaan : 'La mère ou la nourrice qui met son enfant coucher à ses costez, ne le voulant laisser au berceau de peur qu'en criant il l'empeche de dormir ou bien si sensuelle qu'elle aime mieux le coucher près de soy que d'endurer un peu de froid pour l'allaiter, elle pèche mortellement ; car elle se met en péril de le suffoquer.'(...) Ook in de volgende eeuwen werd nog meermaals tegen gebruiken van die aard gereageerd"4.

\section{Abortus}

Chris Vandenbroecke ziet deze "verkapte vorm van kindermoord" als één van de mogelijke strategieën die onze voorouders hebben gevolgd om een "kinderlast op mensenmaat" te realiseren. Een andere, minder vaak gebruikte methode zou erin bestaan hebben een abortus te plegen :

"Tal van abortieve ingrepen konden de gewenste steriliteit in de hand werken. Ook de mensen uit het Ancien Régime wisten dit maar al te goed ; couranter namen ze evenwel hun toevlucht tot ultieme en uit de aard der zaak erg radicale correcties van hun vruchtbaarheid door 'overtollige' kinderen om het leven te helpen of te laten omkomen. Zeker tot en met de $17 \mathrm{de}-18 \mathrm{de}$ eeuw moet dat regelmatig voorgekomen zijn. Het verklaart onder meer waarom de daling van de zuigelingensterfte zo lang op zich liet wachten om eerst tegen het einde van het Ancien Régime waarneembaar te worden"s.

4. C. VANDENBROEKE, p. 140-1.

5. Ibidem, p. 142 . 
Zonder diep in te gaan op de vragen of ook abortus in de context van een wettig huwelijk in de Nieuwe Tijd een bewust gehanteerde techniek geweest is om het kinderaantal te beperken, en op welke schaal dat dan wel zou gebeurd zijn, wil ik toch duidelijk stellen dat vrijwel alle uitvallen van predikanten tegen vruchtafdrijvende handelingen en middelen, expliciet gericht waren tot ongehuwde vrouwen die zich hadden laten zwanger maken. Het ziet er inderdaad naar uit dat meisjes die in een dergelijke oncomfortable situatie waren verzeild geraakt, een abortus vaak als enige uitkomst zagen. Op die manier wilden zij vermijden dat een ongeoorloofde sexuele relatie aan het licht zou komen en dat aldus hun reputatie voor het oog van de buitenwereld zou verloren gaan. Eén voorbeeld uit een sermoen van Joannes Verslype (1656-1735), die o.m. te Kortrijk en te Brugge werkzaam was ${ }^{6}$, moge volstaan om dit punt te illustreren : "Ik moet hier nog eenige andere moorderien voorstellen, daer van ik my schaeme te spreken, maer om dat sy dikwils geschieden, niet en mogen onverlet blyven. Dat is, ten eersten, als eene dogter, Godt uyt haer herte sluytende, niet passende nog op haere maegdelyke eere, nog op haere zaligheid, haer selven overgeeft, als eene onredelyke beeste, aen de vleeschelyke lusten, en siende nu, oft vreesende dat de saeke in het licht zal komen, door dien zy vreest bevrugt te zyn, door kruyden en medecynen, of andere duyvelsche middelen, de vrugt tragten te verdooven, of van hun af te dryven. Vergeeft my dat ik soo klaer uyt segge, en misschien eerbaere ooren wel soude ontstellen, want de grauwelykheyd van de zonde, en dat'er wel zulke elendige gevonden worden, de welke niet en dugten zulke moorderien te bedryven, of daer toe raed en onderrigtinge geven, verbinden my om niet te swygen, en voor die onnoosel schaepkens te spreken, die sy, versmagtende zonder doopsel, naer de helle zenden"'.

Verslype richt zich hier duidelijk tot ongehuwde meisjes, en niet tot getrouwde vrouwen. Deze laatste kregen wél regelmatig te horen

6. Nadere gegevens over het leven en de geschriften van deze figuur vindt men bij $\mathrm{H}$. STORME, "Huwelijksmoraal en lekenmentaliteit in de preken van Joannes Verslype (1656-1735)", in : De Leiegouw XXVIII(1986), p. 373-82.

7. J. VERSLYPE, Historie ende over-een-kominge der vier evangelien, dl. V/1, $2 \mathrm{e}$ uitg. Kortrijk (Joannes De Langhe), 1769, p. 423-3. 
wat ze moesten doen en laten om hun zwangerschap in optimale omstandigheden te laten verlopen, en om te voorkomen dat hun vrucht enig letsel zou worden toegebracht :

"De getrauwde vrauwen mogen hier ook wel vermaent zyn, dat sy, terwylen dat sy draegen, hun selven wel souden wagten van de uyt'er maeten gramschap, van onmaetigheyd, van ongeregelde driften, en appetyten, waer door het menig-mael geschied, dat sy groot leet aen hunne vrugt doen, ja oorsaeke zyn ondertusschen dat sy haer heylig Doopsel niet en kan krygen"8.

Verslype beperkte zijn prenatale voorschriften in dit sermoen tot deze enkele zin, maar sommige van zijn collega's gingen daarop veel dieper in en presenteerden een hele waslijst raadgevingen en verbodsbepalingen. Rumoldus Backx (1650-1703), plebaan van de Antwerpse O.L.V.-kathedraal en auteur van een in de $18 \mathrm{e}$ eeuw erg populaire serie Sermoonen ${ }^{9}$, preekte in 1685 op de tweede zondag van de advent het volgende :

"De sorge die de Ouders moeten draegen voor hun kinderen, moet beginnen van eer sy noch geboren zyn ; van als sy noch gesloten, en gelijck gevangen liggen in het Moeders Lichaem. Van dan af is een Moeder schuldigh de vrucht die sy draeght wel gaede te slaen : en haer te wachten ende t'onthouden van al dat aen de vrucht can schaedelijck zyn oft hinder doen : 't zy van spysen die sy oft selfs ondervonden heeft haer niet wel te becomen, oft weet van andere dat haer in sulcke gelegentheydt niet en dienen : 't zy van loopen, ketsen, dansen, springen, heffen, draegen, recken boven haere macht, oft anderen onmaetigen arbeydt, en al te groote vermoytheyt : 't zy oock, en wel principaelijck, van ongeregelde passien van gramschap, onverduldigheyt, droefheyt, en andere, die een grootgaende Vrouwe haest comen te letten, en haer vrucht geweldigh schaeden"10.

Maar ook de vader werd geregeld gewezen op zijn verantwoordelijkheid terzake. De verkondigers van het Woord Gods knoopten hem in de oren dat hij zijn zwangere echtgenote moest ontzien. Elke

\section{Ibidem, p. 433-4.}

9. Cf. E. COEMANS, "Backx (Rombaut)", in : Biographie Nationale I (1866), k. 608.

10. R. BACKX, CXXV sermoonen op de thien geboden, dl. II, Antwerpen (Petrus Jouret), 1711, p. 105-6. 
vorm van morele of fysieke agressie tegen een "grootgaande" vrouw was totaal uit den boze, gezien de risico's die daaraan verbonden waren voor de vrucht én de moeder. Backx drukte de getrouwde man op het hart :

"wel toe te sien, dat by sijne faute niet en gebeure dat aen sijn draegende huys-Vrouwe oft aen haere vrucht eenigh ongeluck over-come : oft met haer te veel werck en al te grooten arbeyt op te leggen ; oft met haer door quaet comportement, met s'avonts laet uyt te blyven, met tuysschen en spelen, met droncken drincken, oft andere handel die noch erger is, merckelijck te bedroeven ; oft met door vloecken en sweiren, door kyven, tieren, dreygen, en diergelijcke boosheyt haer oorsaeck te geven van groote gramschap, vreese, en ontsteltenisse. Ick swyge van slaen oft stooten, daer het eygender sal zyn van te spreken in het uyt-leggen van het volgende gebodt, dat ons den doodt-slagh ver-biedt, tot den welcken, slaen en stooten gelijck den wegh baent, en lichtelijck daer van oorsaeck is, besonderlijck aen soo teere vrucht als is een kindt in het Moeders Lichaem"

De mij bekende $17 \mathrm{e}$ - en $18 \mathrm{e}$-eeuwse predikanten stellen echter nooit met zoveel woorden dat het risico-gedrag waartegen zij reageren door echtgenoten wetens en willens werd aangewend om een abortus uit te lokken. Deze kerkelijke waarschuwingen getuigen dan ook veel meer van de bekommernis van de Kerk voor het ongeboren leven, en van de lichtzinnige en misschien ook wel onverschillige houding van een aantal mensen, dan wel van het feit dat onze voorouders binnen het kader van een wettig huwelijk soms doelbewust een zwangerschapsonderbreking wensten en betrachtten. Toch mag men die mogelijkheid niet helemaal uitsluiten, vooral omdat diezelfde predikanten - zij het heel sporadisch — getuigen van de bij sommige echtparen aanwezige wil om op één of andere manier aan geboortebeperking te doen. De twee volgende sermoenfragmenten uit het begin van de $18 \mathrm{e}$ eeuw, respectievelijk van Petrus Massemin (1664-1742) en van de reeds genoemde Joannes Verslype wijzen ondubbelzinnig in die richting. Volgens Massemin, pastoor

11. Ibidem, p. 106. Het afranselen van vrouwen werd door het merendeel der predikanten trouwens in alle omstandigheden veroordeeld, ook als ze niet zwanger waren! 
van de "zilveren portie" van de O.-L.-V.-parochie te Brugge ${ }^{12}$ was er zelfs een kleine minderheid van de gelovigen die helemaal kinderloos wenste te blijven :

"Men vind'er, al-hoe-wel zoo gemeenelyk niet, die, als zy trouwen, wenschen geene kinderen voort te brengen, en waer't dat zy de kennisse hadden, zy zouden een Huisvrauwe nemen, die onvrugtbaer is. Zekerlyk deze gaen voort op een ongeregelde wyze, aengezien het bezonderste einde van 't Huwelyk is, kinderen te winnen (...). Dog 't is hier de plaetze niet, om de grouwzaeme schelmstucken, die tot den Hemel om vrake roepen, uit te leggen, die zommige getrouwde uitpeizen, om levende als getrouwde het last der kinderen te ontgaen, gelyk zy zeggen. Dat het hier genoeg zy te weten, dat alle godvreezende menschen in diergelyke zaeken niet vallen, aengezien zy aen de beesten zelve onbekent zyn"13.

Welke gruwelijke en hemeltergende kunstgrepen Massemin concreet in het achterhoofd had toen hij dit sermoen in 1718 neerschreef is onmogelijk uit te maken. Het kunnen abortieve ingrepen geweest zijn, of zelfs infanticide, maar wellicht dacht hij vooral aan coïtus interruptus, steriliserende kruidenmengsels en intrinsiek onvruchtbare sexuele activiteiten. Ook Verslype sprak begrijpelijkerwijze slechts in heel vage bewoordingen over de anticonceptieve attitude van sommige tijdgenoten :

"Ende die door schandelyke middelen hun selven onvrugtbaer maeken, of, ik en derve het niet seggen, wat uytregten, om geene kinders te krygen, zyn pligtig, segt den $\mathrm{H}$. Augustinus, van soo veel moorden, als dat sy konden kinders ter wereld brengen. Och ! wat en gaet'er niet al voor by zomwylen, selfs in den hauwelyken Staet, en bezonderlyk onder arme menschen, als sy met kinders gaen overlast zyn ? Die voorder hier over willen onderrigt zyn, konnen hunne Biegt-vaders te raede gaen"14.

12. Cf. A.-C. DE SCHREVEL, "Massemin (Pierre)", in : Biographie Nationale XIII (1984-1895), k. 939-40.

13. Geciteerd in H. STORME, "Het 18e-eeuws katholiek discours over huwelijk en sexualiteit in de Mechelse Kerkprovincie", in : Documentatieblad Werkgroep Achttiende Eeuw XVII (1985), p. 37.

14. J. VERSLYPE, dl. V/1, p. 433. 


\section{Kinderversmachting in de Middeleeuwen}

Na deze uitweiding over abortus is het de hoogste tijd om over te stappen naar ons eigenlijk studieobject, $\mathrm{nl}$. het bij zich in bed nemen van jonge kinderen en de bestrijding van deze gewoonte door de kerkelijke overheden. We zullen eerst heel even stilstaan bij de Middeleeuwen, om daarna de volle aandacht te richten op de Nieuwe Tijd (16e-18e eeuw). Zonder de Europese context uit het oog te verliezen zal in de eerste plaats de situatie in de Vlaamse regio belicht worden.

Over de frequentie en de karakteristieken van het fenomeen infanticide tijdens de Middeleeuwen is het laatste woord zeker nog niet gezegd. In de gerechtelijke bronnen die Pablo Fernandez voor zijn studie over kindermoord in de Nederlanden in de $14 \mathrm{e}$ en de $15 \mathrm{e}$ eeuw heeft nageplozen, kwam hij slechts heel weinig concrete gevallen op het spoor ${ }^{15}$. Wellicht gaat het om het bekende topje van de ijsberg, aangezien algemeen wordt aangenomen dat infanticide tot op de dag van vandaag een delict is dat gekenmerkt wordt door een zeer hoog "dark number"'16. Wat ons hier echter meer interesseert is Fernandez" conclusie dat er weliswaar arme gezinnen met een grote kinderlast moeten geweest zijn die "in extreme gevallen" tot kindermoord overgingen, maar dat de daders van dit misdrijf door de band genomen "jonge ongehuwde meisjes (zijn) met angst voor de sociale druk die uitgaat van de hen omringende samenleving" "17. Het precieze aandeel van de gehuwden t.o.v. het totale aantal van kindermoord verdachte of beschuldigde vrouwen deelt Fernandez niet mee, maar hij stelt wel dat "de overgrote meerderheid van de beschuldigden" ongehuwd was ${ }^{18}$. En hij voegt er onmiddellijk aan toe dat "in die

15. P. FERNANDEZ, "Het verschijnsel kindermoord", p. 132 : "Vooreerst dient men goed voor ogen te houden dat de in de bronnen aangetroffen gevallen van kindermoord zeer weinig talrijk zijn (...). Ter illustratie slechts dit : in de ca. 100 doorgenomen baljuwsrekeningen tussen 1331 en 1509 worden slechts 7 gevallen van infanticide vermeld (...). In alle Audiëntieregisters tussen 1386 en 1504 komen welgeteld 6 gevallen voor $(\ldots)$ ".

16. S. FABER, "Kindermoord", p. 235 en p. 237.

17. P. FERNANDEZ, p. 132.

18. Ibidem, p. 120. Hetzelfde werd door andere onderzoekers voor andere periodes en regio's vastgesteld. Zie bv. P. HOFFER, N. HULL, Murthering mothers. Infanticide in England and New England, 1558-1803, New York, 1981, p. 97 en p. 109. 
gevallen waar de moeder wel gehuwd was, het meestal om niet bewezen, subtielere gevallen van infanticide ging" lere" of "accidentele" vormen van kindermoord behoort o.m. het verstikken van baby's die Middeleeuwse ouders vaak bij zich in bed namen. Op gezag van Flandrin schrijft Fernandez dat "zeer vele, vooral kerkelijke bronnen, in dit verband spreken van vrijwillig verstikken van zijn kinderen" en dat vele ouders hierin een middel zagen "om hun ongewenste nakomelingen zonder veel risico kwijt te raken" terugkomen, maar nu reeds noteren we dat Fernandez in de loop van zijn onderzoek van deze praktijk geen sporen heeft terug gevonden voor de laat-middeleeuwse Nederlanden ${ }^{21}$.

Nog voor wat de Middeleeuwen betreft laat Klaus Arnold i.v.m. het bij zich in bed nemen van jonge kinderen een heel ander geluid horen. Hij ontkent immers formeel dat zoiets doelbewust zou gebeurd zijn om ongewenste kinderen uit de weg te ruimen: "Mütter nahmen ihre Kinder auch im Mittelalter sicher nicht in der Absicht in ihr Bett, sie zu ersticken. Ebenso wie die uns seltsam anmutenden Wickelsitten diente diese Massnahmne in den nördlichen Breiten in erster Linie der Kälteabwehr oder was schlicht van Armut und Mangel diktiert" 2 . Volgens hem waren veruit de meeste sterfgevallen toe te schrijven aan de onvoorzichtigheid (Fahrlässigkeit) van ouders en minnen. Even later geeft hij wel toe dat er occasioneel misschien echtparen geweest zijn die een zuigeling in bed lieten stikken, omdat de kinderlast hen anders boven het hoofd dreigde te groeien. Hij benadrukt echter dat zoiets op geen enkele manier uit de bronnen is af te leiden : "Selbst wenn es de facto

19. P. FERNANDEZ, p. 120.

20. Ibidem, p. 130-1. Gelijklopende conclusies voor middeleeuws Engeland : R.H. HELMHOLTZ, "Infanticide in the province of Canterbury during the fifteenth century" in : History of Childhood Quarterly 2(1975), p. 380-2 ; B.A. HANAWALT, "Childrearing among the lower classes of late medieval England", in : Journal of Interdisciplinary History 8 (1977), p. 10.

21. P. FERNANDEZ, p. 131.

22. K. ARNOLD, Kind und Gesellschaft in Mittelalter und Renaissance. Beiträge und Texte zur Geschichte der Kindheit, (Sammlung Zebra: Reihe B, Bücher für die Ausbildung und die Weiterbildung der Erzieher, Band 2), Paderborn-München, 1980, p. 49. 
gelegentlich geschehen sein mag, hat niemand den Verdacht geaüssert, dass in der Absicht gehandelt wurde, den Kinderreichtum zu begrenzen. Zumindest lässt sich in den zeitgenössischen Quellen kein Hinweis finden, dass Kindeserdrückung als Ersatz für kontrazeptive Massnahmen gedient hat"23.

\section{Gecamoufleerde kindermoord of spijtig ongeval ?}

Kerkelijke actie in de Nieuwe Tijd.

I.t.t. Klaus Arnold beschouwt Chris Vandenbroeke het versmachten van zuigelingen wel degelijk als een primitieve vorm van gezinsplanning, die ook in de Nieuwe Tijd in voege bleef. Als ik hem goed begrijp beweert hij :

1. dat sommige mensen doelbewust een kind uit de weg ruimden en het overlijden nadien als een ongeluk voorstelden om geen verdenking van kindermoord op zich te laden ;

2. dat men in kerkelijke middens op de hoogte was van het bestaan van dit maneuver en dus heel goed besefte dat veel zogezegde ongelukken in werkelijkheid gecamoufleerde kindermooren waren ;

3. dat de Kerk niet uitsluitend, maar toch vooral om die reden het bij zich in bed nemen van zuigelingen heeft veroordeeld en bestreden.

Dit alles zou moeten blijken uit een tekst van Joannes Benedicti, die Vandenbroeke overigens ten onrechte als bisschop van Lyon betitelt. In werkelijkheid was hij een geleerde franciscaan die wel in 1581 en 1582 als predikant in Lyon is opgetreden ${ }^{24}$. Het citaat in kwestie is afkomstig uit La somme des pechez, een lijvig handboek van casuïstiek dat Benedicti in 1584 publiceerde ten behoeve van geestelijken en leken. Te oordelen naar het aantal herdrukken en bewerkingen dat op de markt kwam, kende het boek een behoorlijk

23. K. ARNOLD, p. 52.

24. Meer bio- en bibliografische gegevens over deze figuur, waarvan de geboorte- en sterfdata niet bekend zijn, vindt men bij L. WADDING, Scriptores Ordinis Minorum, nieuwe uitg. Rome, 1906, p. 131 ; J.H. SBARALEA, Supplementum et castigatio ad Scriptores trium Ordinum S. Francisci, dl. II, nieuwe uitg. Rome, 1921, p. 40 ; E. D'ALENCON, "Benedicti Jean", in : Dictionnaire de théologie catholique II/1 (1923), k. 601-2 ; R. D'AMAT, "Benoît Jean", in : Dictionnaire de biographie française 5 (1951), k. 1439. 
succes $^{25}$. Benedicti behandelde het bij zich in bed nemen van kinderen bij de bespreking van het vijfde gebod, tussen twee paragrafen respectievelijk gewijd aan infanticide en abortus. Vooraleer na te gaan of de passus uit La somme des pechez die Vandenbroeke aanhaalt inderdaad bewijst wat hij er mee wil aantonen, moet nog worden aangestipt dat Vandenbroeke Benedicti slechts gedeeltelijk heeft geciteerd. De franciscaan voegde er immers nog de volgende o.i. erg relevante bedenkingen aan toe :

“Que si elle s'endort \& l'estouffe, elle est homicide, \& si est excommuniee : peché reserué à l'Euesque, duquel un simple curé n'a pas puissance d'absoudre. On leur deuroit imposer la penitence de cinq ans ou plus, selon les canons anciéns. Les meres doyuent bien regarder à cecy, et qu'à tout le moins le lict soit grand \& large, \& quelque chose entre elles \& l'enfant, si elles n'ont le moyen de coucher ailleurs, à fin qu'estans esloingees ils soyent hors de peril. Il y a vn certain Docteur, qui semble aucunement exuser ceux que sont si pauures, qu'ils n'ont pas le commodité d'auoir de grands licts, ny les berceaux, \& autres choses necessaires. Quant à cela ie m'en rapporte à leur conscience. $\mathrm{P}$ [eché]. $\mathrm{M}$ [ortel]"26.

Om nu tot de kern van zaak te komen moeten wij ons afvragen of men op grond van het getuigenis van Benedicti Vandenbroekes conclusies kan onderschrijven.

Dat sommige echtparen pasgeboren baby's bij zich in bed namen met de al dan niet expliciete bedoeling ze te laten verstikken, of tenminste met de stille hoop dat er een ongeval zou gebeuren is denkbaar, en het lijkt niet onmogelijk dat het soms inderdaad gebeurde. Volgens Vandenbroeke was het de wil om de kinderlast

25. Wij consulteerden een door de theologische faculteit van Parijs herziene uitgave uit 1602 waarvan de volledige titel als volgt luidt : J. BENEDICTI, La somme des pechez, et le remede d'iceux, comprenant tous les cas de conscience, \& la resolution des doubtes touchant les pechez, simonies, usures, changes, commerces, censures, restitutions, absolutions, \& tout ce qui concerne la reparation de l'ame pecheresse par le Sacrement de la Penitence, selon la doctrine des saints conciles, theologiens, canonistes et iurisconsultes, Hebrieux, Grecs \& Latins. Traicté tres-utile aux ecclésiastiques, aux prestres, curez, confesseurs, predicateurs \& penitens : au magistrat \& troisiesme estat, \& en somme à tous ceux qui veulent obtenir le salut, Parijs, 1602.

26. J. BENEDICTI, p. 107. 
wat af te remmen die hen daartoe aanzette. Flandrin denkt in dezelfde richting : ook hij ziet het verstikken van kinderen als een methode die geschikt was om zich ongestraft van overtollige nakomelingen te ontdoen ${ }^{2}$. Jacques Gélis, een specialist van de geschiedenis van de geboorte en al wat daarbij komt kijken, sluit zich globaal gezien bij Flandrin aan, maar vraagt zich toch af of het niet vooral op één of andere manier gehandicapte baby's geweest zijn die op die manier uit de weg werden geruimd. Hij oppert dat arme lieden het wellicht niet opportuun achtten een gebrekkig schepseltje dat hen misschien jarenlang handenvol geld zou kosten, in leven te houden. Temeer omdat het in hun ogen toch al ten dode was opgeschreven, en hoe dan ook maar weinig overlevingskansen had ${ }^{28}$. Dit alles blijft echter louter hypothetisch zolang er geen stevig bewijsmateriaal wordt voorgelegd. $\mathrm{Nu}$ kan je hoogstens stellen dat Benedicti's woorden niet direct in tegenspraak zijn met deze hypothese, maar ze bieden er anderzijds ook geen enkele steun voor ! Van intentioneel handelen om te doden is immers nergens sprake, alleen van onverantwoorde risico's. Ook over het enscèneren van ongelukken om wat dan ook te camoufleren, rept Benedicti met geen

27. J.L. FLANDRIN,p. 172 : “Depuis longtemps, les couples légitimes avaient à leur disposition d'autres moyens de se débarrasser d'enfonats superflus sans tomber sous le coup des lois (...). L'oppression ou la suffocation d'enfant est sans doute l'un de ces moyens". François Lebrun constateerde een algemeen gebrek aan elementaire voorzorgsmaatregelen rondom het pasgeboren kind in het Ancien Régime. Het bij zich in bed nemen van zuigelingen situeert hij tegen deze achtergrond, en hij vraagt zich af: "Ne s'agit-il pas, au même titre que pour certains avortements, d'une stratégie (plus ou moins consciente et allant dans le sens de la sélection naturelle) de limitation du nombre des enfants au sein de la famille? On peut aun moins se poser la question, à la suite de Philippe Ariés : 'Le fait d'aider la nature à faire disparaître des sujest aussi peu doues d'un être suffisant, n'était pas avoué, mais il n'était pas non plus considéré avec honte. Il faisait partie des choses moralement neutres, condamnées par les éthiques de l'Eglise, de l'Etat, mais pratiquées en secret, dans une demiconscience, à la limite de al volonté, de l'oubli, de la maladresse'”. (F. LEBRUN, La vie conjugale sous l'Ancien Régime, Parijs 1975, p. 152-3).

28. J. GELIS, L'arbre et le fruit. La naissance dans l'Occident moderne (XVIe-XIXe siècle), Parijs, 1984, p. 483: "Mais quels étaient donc ces enfants oppressés, suffoqués ? Statuts et rituels n'en disent rien. Il serait pourtant intéressant de savoir si ces pauvres enfants n'étaient pas de jeunes handicapés, des rachitiques ou des débiles, que les parents estimaient avoir peu de chance de sauver. Des créatures qui, au mieux, resteraient pendant des années à la charge d'un couple déjà tellement démuni". Gélis vermoedt dat deze geruisloze verdwijningen van gehandicapte baby's vooral voorkwamen in gezinnen uit de armste stedelijke milieus. 
woord. Het is mij dan ook een volkomen raadsel hoe Vandenbroeke er toe komt te beweren dat de Kerk besefte dat het in werkelijkheid ging om een verkapte vorm van kindermoord.

Documenten waaruit zou blijken dat men in kerkelijke middens weet had van ouders die bewust aanstuurden op een "ongeluk", of er tenminste geen drama van maakten als zo'n ongeval zich buiten hun wil om voordeed, zijn mij onbekend. Ook de $17 \mathrm{e}$ - en $18 \mathrm{e}$-eeuwse predikanten uit onze gewesten hebben nooit vermoedens in die zin geuit. Niemand van de mij bekende auteurs suggereert dat er naast onverantwoorde onachtzaamheid ook wel eens kwaad opzet mee gemoeid was. Jacobus Marchantius (1585-1648) bv., pastoor van het plaatsje Couvin in het prinsbisdom Luik ${ }^{29}$ en auteur van een in de $17 \mathrm{e}$ eeuw razend populaire Hortus pastorum ${ }^{30}$, verweet de ouders in dit verband slechts schuldige nalatigheid :

"peccant qui per negligentiam infantes in eodem lecto dormientes suffocant, estque hic gracitas culpae juxta gravitatem negligentiae"31.

Zijn getuigenis is der te interessanter omdat hij letterlijk uit de biecht spreekt. Vanuit zijn jarenlange ervaring als biechtvader had hij weet van verscheidene gevallen waarbij kinderen in het ouderlijk bed om het leven waren gekomen, hetzij omdat ze uit bed waren gevallen, hetzij omdat ze in het beddegoed verstrikt waren geraakt, of nog omdat ze gestikt waren aan de borst van hun moeder die tijdens het zogen in slaap gesukkeld was. Dat hij deze voorvallen als ongewilde en door de betrokken moeders als bijzonder pijnlijk ervaren ongelukken beschouwde kan niet betwijfeld worden. Hij verklaart immers dat de moeders die bij hem te biechten kwamen hun onvoorzienigheid bij het ontwaken met bittere tranen bekloegen :

29. Meer gegevens bij T.-J. LAMY, "Marchant (Jacques)", in : Biographie Nationale XIII (1894-1895), k. 447-50 ; T. REJALOT, Un écrivain Couvinois du XVII ${ }^{\text {me }}$ siècle. Jacques Marchant. Sa vie - ses auvres. Namen, 1908 ; E. AMMAN, "Marchant Jacques", in : Dictionnaire de théologie catholique IX/2 (1927), k. 2004.

30. Dom Thierry Réjalot signaleert ruim 40 edities van dit pastoraaltheologisch handboek dat voor het eerst verscheen in Bergen in 1626-1627. Ik consulteerde een 19e-eeuwse uitgave die naast de oorspronkelijke Latijnse tekst ook een (niet altijd even accurate) Franse vertaling geeft : J. MARCHANT, Le jardin des pasteurs. Traduction française avec le texte Latin, Uit het latijn vertaald door E. Berton, $4 \mathrm{dln}$., 3e uitg. Parijs, 1862.

31. J. MARCHANTIUS, dl. IV, p. 180. 
"Unde mihi compertum est ex ipsarummet confessione, modo e lecto decidisse infantes, modo ipso stragulo suffocante, modo ipsis uberibus continui lactis fluxu in obdormiscentis os nimis abunde profluentibus, infantes enecatos fuisse, cum maximo matrum sese expergiscentium et imprudentiam suam, sed sero nimium, deplorantium lamento" 32 .

Krokodilletranen bedoeld om de biechtvader op een dwaalspoor te brengen, opdat hij hen niet zou verdenken van kindermoord ? Best mogelijk, maar dan zou Marchantius wel erg naïef moeten geweest zijn, en bovendien is het dan moeilijk vol te houden dat men in kerkelijke kringen op de hoogte was van het feit dat sommigen infanticide als ongeluk camoufleerden...

Rumoldus Backx bracht het bij zich in bed nemen van kinderen o.m. ter sprake in een sermoen op de vierde zondag na Pasen in 1686, waarin hij zich voornam allerlei vormen van onvrijwillige doodslag te behandelen, waarvoor de "uytdruckelijcken wille ende meyninge (...) om eenen doodtslagh te doen" dus niet aanwezig was ${ }^{33}$. Ook Petrus Massemin lijkt in een sermoen uit 1718 te aanvaarden dat het echte ongelukken waren, hoewel de ouders daarom nog niet vrijuit gingen :

“' $t$ Is eene vervaerelyke, en t' zaemen eene onbegrypelyke zake, dat'er moeders konnen gevonden worden, die door hunne zorgloosheid en onagtzaemheid, de oorzake van de dood zyn van die, aen welke zy het leven hebben gegeven. Het is zekerlyk niet genoegzaem te zeggen, dat het een ongeluk is, dat zy die meeninge niet gehad hebben enz. : want zy konden en moesten weten, dat'er zoo een gevaer in zoo een werk gelegen is. De mannen van zulke vrouwen kunnen ook niet verschoont worden, om dat zy diergelyke zaken moeten beletten, en hunne vrouwen vervaert maken"34.

32. Ibidem, p. 180.

33. R. BACKX, $C X X V$ sermoonen, dl. II, p. 264. Zo beschouwt hij kinderen als de "moorders en doodt-slaegers van hun Ouders", als zij "door hun wederspannigheydt, en quaedt comportement de Ouders soo bedroeven dat sy hun voor den tydt doen sterven, en (gelijck men seyt) den nagel van hun doodt-kist zyn" (p. 267). Over "die Ouders, de welcke de jonge en teere kinderkens al te vroeg bij hun in't bedde leggen", zie p. 273-4.

34. P. MASSEMIN, Sermoenen op de sondagen, dl. II, Brugge (Joseph Van Praet), 1765 , p. 304. 
Joannes Verslype klaagt over de "onvoorsigtigheyd, en onagtzaemheyd van zulke ouders" 35 , en wijst op "het gevaer dat'er is, van zomwylen in de slaep onwetens de kinders te versmagten" ${ }^{36}$. Nogmaals, niemand, maar dan ook niemand suggereert dat er soms voorbedachtheid en kwaad opzet mee gemoeid was. Ignatius Albertus De Vloo (1716-1775), die van 1758 tot aan zijn overlijden pastoor was van de "gouden portie" van de O.-L.-V.-parochie in Brugge ${ }^{37}$, is daarover wellicht nog het duidelijkst : Over "die Moeders, die eene gewoonte maeken van hunne teere en onnoozele Kinderkens, by hun en nevens hun te nemen in de ruste, niet zonder groot gevaer van de zelve dood te liggen of te versmagten" zegt hij in een preek voor de vijfde zondag na Pinksteren :

"Ik weet, dat zy dit niet bestaen uyt en met die kwaede meeninge, maer ondertusschen hunne goede meeninge kan het gevaer niet wegnemen ; en dan gaen zy maer eerst het gevaer bemerken, alswanneer zy het gedwongen zyn te betreuren"38. De Vloo raakt hier een punt aan dat waarschijnlijk hét grote probleem was waarmee de Kerk in het algemeen en de predikanten in het bijzonder hadden af te rekenen, $\mathrm{nl}$. dat veel mensen de kerkelijke waarschuwingen en verbodsbepalingen niet au sérieux namen en gewoon weglachten. Tot het te laat was! Predikatie over dit thema was dan ook essentieel bedoeld om de toehoorders te wijzen op de risico's, en hen ervan bewust te maken dat het niet om denkbeeldige maar om reële gevaren ging. Het viel blijkbaar niet mee om hen daarvan te overtuigen, ook al omdat het naast zich te slapen leggen van zuigelingen een oeroude, diep ingewortelde gewoonte was, die de Kerk al sinds de vroege Middeleeuwen met man en macht bestreed. Zonder al te veel succes, aangezien men tot aan het einde van de $18 \mathrm{e}$ eeuw, en wie weet nog langer, op dit punt moest blijven hameren $^{39}$.

\section{J. VERSLYPE, Historie, dl. V/1, p. 434.}

36. Ibidem, dl. VII/1, p. 450 (cursivering van ons).

37. Een beknopte biografie van kanunnik De Vloo vindt men bij A.T. VAN BIERVLIET, "Vloo, Ignaas Albert de, predikant", in : Nationaal Biografisch Woordenboek 3 (1968), k. 921-3.

38. I.A. DE VLOO, Sermoenen, dl. V, Brugge (Joseph De Busscher), 1790, p. 149. 39. J. GELIS, M. LAGET, M.-F. MOREL, Entrer dans la vie, p. 124 : "Malgré les interdits, la plupart des nouveau-nés français ont longtemps été couchés avec leur mère ou leur nourrice". Flandrin constateerde wel een zekere vooruitgang tijdens de 18 e eeuw (art. cit., p. 174-5). 
Waarom die van eeuw tot eeuw herhaalde waarschuwingen en dreigementen zo weinig uithaalden zullen we straks proberen uit te vissen, maar eerst moeten we nog even stilstaan bij het betoog van Jean-Louis Flandrin. Deze gerenommeerde Franse specialist van de geschiedenis van liefde, huwelijk en sexualiteit, die bovendien als geen ander vertrouwd is met kerkelijke bronnen, is er nl. net als Vandenbroeke van overtuigd dat baby's soms opzettelijk in het ouderlijk bed werden verstikt. Het lijkt hem nogal vreemd dat de Kerk aan het fenomeen kinderversmachting zoveel aandacht zou besteed hebben als er louter en alleen sprake zou geweest zijn van banale ongelukken ${ }^{40}$. Volgens hem was er meer aan de hand, en vond de Kerk sommige sterfgevallen van baby's in het echtelijke bed wel degelijk verdacht. Hij baseert zich daarvoor op de analyse van 37 lijsten van aan de bisschop voorbehouden zonden uit de periode 1200-1800. In 26 daarvan bleek kinderversmachting een casus reservatus. Nu betekent dat op zich weinig meer dan dat men het nodig oordeelde om de gewoonte van kinderen bij zich in bed te nemen met de grote middelen te bestrijden. Maar er is meer : in 10 lijsten was uitdrukkelijk sprake van vrijwillige verstikking ! ${ }^{41}$ Flandrin geeft in voetnoot de exacte referenties naar zijn bronnen, maar citeert jammer genoeg geen enkele van die tien gevallen. Het zou ons te ver hebben geleid om dat allemaal te gaan natrekken, en er is trouwens geen enkele reden om Flandrins deskundigheid en intellectuele eerlijkheid te betwijfelen. Toch lijkt het niet erg waarschijnlijk dat het aan de bisschop reserveren van kinderversmachting in de eerste plaats bedoeld was om gecamoufleerde kindermoorden te bestrijden. Vrijwillige kinderverstikking was immers hoe dan ook een voorbehouden zonde : oppressio infantium was in dat geval zonder meer gelijk te stellen met homicidium voluntarium, wat in alle bisdommen gereserveerd was $!^{42}$

40. J.-L. FLANDRIN p. 172. Wat daar zo vreemd aan is begrijp ik niet goed, want het lijkt toch volkomen normaal dat de Kerk zich inspande om dergelijke ongelukken te vermijden, ook als ze geen twijfels had over de oprechtheid van de ouders die het sterfgeval als ongeluk voorstelden.

41. Ibidem, p. 173 : "Or plusieurs listes de cas réservés affirment clairement qu'il ne s'agit pas toujours d'un accident : dix sur vingt-six parlent d'oppression ou de suffocation volontaire, et ce caractère volontaire n'est pas démenti par les autres listes, plus concises."

42. Zie ook de redenering terzake van J. Pauwels, een $18 \mathrm{e}$-eeuwe specialist inzake gereserveerde zonden, die verder nog uitvoerig aan bod komt. 
Wat er ook van zij, Flandrins argumentatie is in geen geval van toepassing op onze gewesten. Uit de geschriften van Josephus Pauwels OFM Recol. ${ }^{43}$ en Fidelis Mosae-Trajectini OFM Cap. ${ }^{44}$, die in de $18 \mathrm{e}$ eeuw beiden een lijvig tractaat publiceerden over aan de bisschop gereserveerde zonden, blijkt immers dat oppressio vel suffocatio infantium in geen enkel Vlaams bisdom ooit een casus reservatus geweest is. Pauwels bestudeerde de bisdommen Antwerpen, 's-Hertogenbosch, Kamerijk, Keulen, Gent, Luik, Mechelen, Namen en Roermond, en stelde in hoofdstuk XXII (De prolis oppressione) vast dat deze zonde alleen in Luik en Namen gereserveerd was ${ }^{45}$. Fidelus van Maastricht gaf een overzicht van de situatie in Brugge, Luik, Keulen, Mechelen, Gent, Antwerpen, Doornik, Roermond, Namen, Ieper en Saint-Omer en noemde alleen Luik, Namen en Saint-Omer als diocesen waar kinderversmachting op één of andere manier gereserveerd was ${ }^{46}$. In de "Vlaamse" bisdommen Brugge, Ieper, Gent, Antwerpen en Mechelen was dat dus duidelijk niet het geval, met deze kleine nuance dat Pauwels aanstipt dat de casus "homicidium" in Gent zo ruim werd opgevat dat ook onvrijwillige kinderversmachting daaronder kon begrepen worden :

"Tertio, reservari Homicidium commissum ex gravi negligentia (...) cavendi eum casum, ut si mater aut nutrix, praevidens periculum oppressionis, ne noctu teneatur surgere, condormiat parvulo, secuto effectu mortis" ${ }^{47}$.

43. Cf.P. BERGMANS, "Pauwels (Joseph)", in : Biographie Nationale XVI (1901), k. 763-4.

44. Het titelblad van zijn boek vermeldt dat Fideel van Maastricht theologie en $H$. Schrift doceerde te Brugge, wellicht in het Kapucijnenklooster aldaar. Een biografische studie over deze figuur is mij niet bekend.

45. J. PAUWELS, Tractatus theologicus de casibus reservatis in dioecesibus Antverpiensi, Buscoducensi, Cameracensi, Coloniensi, Gandavensi, Leodiensi, Mechliniensi, Namurcensi, Ruraermundenci, 3e uitg. leuven (Joannes Jacobs), 1755, p. 429: "In Antverpiensi, Buscoducensi, Cameracensi, Coloniensi, Gandavensi, Mechliniensi, Ruraemundensi nihil exprimitur de hoc casu. In Leodiensi reservatur, Prolis Oppressio. In Namurcensi Oppressio tenellorum".

46. FIDELIS MOSAE-TRAJECTINI, Tractatus theologicus de casibus reservatis Summo Pontifici, epescopalibus in diversis dioeceibus Brugensi, Leodiensi, Coloniensi, Mechliniensi, Gandenso, Antwerpiensi, Tornacensi, Ruremundensi, Namurcensi, Iprensi, Audomarensi et regularibus, 2e verb. uitg. Ieper (Thomas Franciscus Walwein), [s.a.] (ca 17153), p. 146-7 (Luik), p. 180 (Namen) en p. 197-8 (Saint-Omer).

47. J. PAUWELS, Tractacus, p. 253-4. 
I.t.t. de andere genoemde bisdommen speelde het in Gent immers geen rol of een doodslag vrijwillig was of niet : volgens het Gentse Pastorale volstond het dat men uit nalatigheid onrechtstreeks en ongewild de oorzaak was van iemands dood, om de casus op te lopen $^{48}$. De Vlaamse bisschoppen uit de Nieuwe Tijd vonden de gewoonte van het zich in bed nemen van kinderen dus blijkbaar lang niet zo onrustwekkend als vele van hun Franse collega's. Ze achtten het in elk geval niet nodig om drastisch in te grijpen, door er bv. een voorbehouden zonde van te maken, of de overtreders met excommunicatie te bedreigen. Nochtans wist men ook bij ons heel goed dat dergelijke maatregelen in andere bisdommen wél in voege waren. Predikanten maakten van deze voorbeelden trouwens dankbaar gebruik om hun publiek te overtuigen van de enormiteit van deze zonde. Backx bv. preekte in 1686 dat :

"het in sommige Bisdommen op straffe van den ban, op pene van excommunicatie aen de Ouders verboden [is] de kinderkens voor eenen sekeren tydt en ouderdom by hun in't bedde te laeten slaepen. Elders is het eenen cas, die de Bisschoppen reserveren, sonder aen andere Bicht-Vaders, ten waere aen seer weynige, de macht te geven van daer van t'absolveren. Dat isser hier van, ende over al, dat de Ouders dit peryckel kennende, ende daer van genoegh gewaerschouwt zynde, pligtig zyn van groote sonde, tegen Godts vyfde Gebodt, dat den doodt slagh verbiedt, niet alleenelijck als hun soodaenigh ongeluck over comt, maer oock als sy hun, ende hunne kinderen daer toe in peryckel stellen ${ }^{49}$ ".

In Luik en Namen was het onvrijwillig verstikken van kinderen in bed wél een gereserveerde zonde, wat er op kan wijzen dat de toestand daar ernstiger was dan in de Mechelse kerkprovincie, of toch als dusdanig werd aangevoeld. Alleen wanneer een kindje effectief gestorven was, moesten de betrokken ouders of minnen zich tot de bisschop of een door hem gedelegeerde priester wenden om de absolutie te bekomen. In het bisdom Saint-Omer echter volstond het

48. Ibidem, p. 252 : "In Gandavensi ponitur Homicidium, de quo sic loquitur Pastorale : Per Homicidium (intellige) qoud re ipsa commissum est, sive sit voluntarium sive casuale, ex culpa lata, aut peccando mortaliter in negligentia cavendi eum casum".

49. R. BACKX, CXXV sermoonen, dl.II, p. 274. 
naakte feit van een kind dat nog geen vol jaar oud was bij zich in bed te nemen, om de casus op te lopen, dus ook zonder dat zich een incident had voorgedaan ${ }^{50}$. Pauwels benadrukt sterk dat het in Luik en Namen hoegenaamd niet nodig was dat de volwassenen in kwestie opzettelijk handelden om te doden. In dat geval zouden ze hoe dan ook een voorbehouden zonde begaan, $\mathrm{nl}$. vrijwillige doodslag die in beide diocesen aan de bisschop gereserveerd was. Als de wetgever vrijwillige kinderversmachting viseerde, had hij geen enkele reden om van oppressio infantium een aparte casus te maken, want dat zou een overbodige en ronduit belachelijke overlapping betekend hebben $^{51}$ ! Oppressio infantium sloeg volgens Pauwels dus onmiskenbaar op ouders of minnen die zo onvoorzichtig waren om een kleintje bij zich in bed te nemen en het op die manier bloot te stellen aan enorme risico's. Zoiets was altijd doodzonde, en ingeval het kindje daadwerkelijk stierf bovendien een gereserveerde zonde. Onoverwinnelijke onwetendheid omtrent die risico's kon nooit als geldig excuus worden ingeroepen ${ }^{52}$. In het prinsbisdom Luik voerde men trouwens permanent een preventieve campagne om de kersverse moeders op die gevaren te wijzen. Wanneer een kraamvrouw ongeveer 40 dagen na de bevalling haar kerkgang deed, moest de pastoor haar volgens het Luikse Rituale het volgende voorhouden :

"C'est avec justice, que vous venez en ce saint lieu pour rendre vos actions de graces à Dieu, de ce qu'il vous a delivre des douleurs \& des dangers de l'enfantement, \& à même temps luy consacrer \& offrir le fruit de votre ventre, avec toutes vos actions, que vous devez rapporter en son honneur, à sa gloire, \& à l'édufucation de son Eglise : Prennez garde, que cet enfant ne tombe en péril, soit spirituel, faute d'instruction dans la Foy

50. J. PAUWELS, p. 436 en FIDELIS MOSAE-TRAJECTINI, p. 198.

51. J. PAUWELS, p. 434-5 : "Respondeo, Oppressionem parvuli, etiam indirecte volitam \& in causa remota, idcirco reservatam esse, qoud Oppressio parvuli directa \& in se intenta, contineatur sub Homicidio voluntario antea reservato ; ergo dum deinceps reservatur distincto termino Oppressio ven tenelli, debet haec alio sensu accipi, ne sit notorie ridicula repetitio : alioquin enim praesens casus hunc sensum dabit ; Homicidium voluntarium prolis; quod perinde ridiculum foret, ac si, reservato prius Homicidio voluntatio, deinceps per distinctum terminum reservaretur Homicidium adulti, sacerdotis, virginis \&c."

52. J. PAUWELS, p. 431-2. 
Catholique, \& dans la pratique des Commandemens de Dieu \& de son Eglise ; soit temporel ; faute d'en prendre soin pendant la foiblesse de son corps. Sur tout gardez-vous pendant qu'il est encore tendre, de le tenir prés de vous dans un même lit, de crainte qu'en dormant vous ne luy fassiez tort sans y penser, dont vous devriez répondre devant Dieu, \& devant les hommes"s3.

In de Mechelse kerkprovincie bestond een dergelijke voorlichting of waarschuwing ter gelegenheid van de kerkgang niet.

Dat moge volstan om aan te tonen dat Flandrins argumentatie niet van toepassing kan zijn op de Vlaamse regio. Er moet ook nog gewezen worden dat het citaat uit Benedicti, dat Vandenbroeke vermoedelijk aan Flandrin ontleend heeft, door deze laatste toch enigszins anders geïterpreteerd werd. Flandrin relativeert niet alleen heel sterk de frequentie van het aantal vrijwillige, doelbewuste kinderversmachtingen, maar hij ziet Benedicti's betoog ook uitsluitend als een indicatie van de onvoorzichtigheid en het egoïse van vele ouders en minnen. Hij leidde het citaat uit Benendicti's $L a$ somme dez pechez als volgt in :

"De ce qui a été dit de l'oppression d'enfant, il ne faudrait pas tirer la conclusion qu'elle était volontaire dans la majorité des cas. L'oppression dans le lit conjugal ne peut au contraire avoir été un moyen tentant d'éliminer volontairement les enfants indésirables que parce qu'elle était normalement accidentelle. Mais cet accident ne met pas en cause que l'ignorance des parents : elle s'explique aussi par leur négligence. Sachant qu'il est dangereux de faire dormir un nourrisson dans leur lit, beaucoup semblent avoir pris ce risque pour s'épargner des dépenses ou de la fatigue. C'est ce que leur reproche, par exemple, Benedicti" ${ }^{54}$.

\section{Houding van de gelovigen}

De vraag is alleen of onze voorouders zich wel realiseerden dat het bij zich in bed nemen van jonge kinderen zo riskant was. M.a.w., hoe reageerden zij op de veelvuldig geslaakte alarmkreten van

53. Rituale sive parochiale Leondiense in quo constinentur ea parochos praestare oportet in administratione Sacramentorum, et aliis plerisque ad officcium parochiale spenctantibus, Luik, 1701, p. 224.

54. J.-L. FLANDRIN, p. 182. 
kerkelijke zijde ? Waarom bleven zij vrij massaal vasthouden aan de voorouderlijke gewoonte, en waarom legden zij de kerkelijke waarschuwingen schijnbaar zo gemakkelijk naast zich neer ? Waren zij louter materieel gezien wel in staat om de kerkelijke voorschriften na te leven ? En kon de Kerk dan geen begrip opbrengen voor hun motieven om kinderen bij zich in bed te nemen ? De predikanten kunnen ons een eind op weg helpen om deze vragen te beantwoorden, en laten ons toe om enig inzicht te verwerven in de mentaliteit van onze voorouders.

Bijna alle historici die het bij zich in bed nemen van zuigelingen bestudeerden, gingen er zonder meer van uit dat de Kerk het bij het rechte eind had wanneer ze dat als een uiterst gevaarlijke praktijk verbood. Alleen de auteurs van Entrer dans la vie ${ }^{55}$ schijnen daaraan te twijfelen en stellen dat het verbod om kinderen bij zich in bed te nemen veeleer culturele wortels heeft. $\mathrm{Zij}$ beschrijven hoe het oude kerkelijk verbod opnieuw en in gewijzigde vorm is opgedoken in de $18 \mathrm{e}$-eeuwse medische literatuur. Geneesheren en vroedvrouwen gingen zelf zover elk nachtelijk contact tussen volwassen en baby's te verbieden, in naam van de medische theorie van de uitwisseling van lichaamsvochten. Via het transpiratievocht zou het kindje vitale lichaamssappen meedelen aan de volwassen bedgenoot en zou op die manier fel verzwakken. Het gewone volk had dan weer schrik om kinderen bij de grootouders te laten slapen, omdat een populaire volkswijsheid wilde dat kleine jongens die bij bejaarde vrouwen sliepen impotent zouden worden ! Deze sexuele sanctie houdt een duidelijke verwijzing in naar het oeroude incestverbod, waarvan men ook sporen terugvindt in $20 \mathrm{e}$-eeuwse psychoanalytische theorieën die speculeren over de mogelijk verstoorde psychische ontwikkeling van kinderen die de slaapkamer van hun ouders delen ${ }^{56}$. Dat bracht Gélis, Laget en Morel tot de overtuiging dat de oorsprong van dergelijke verbodsbepalingen van culturele aard is, en niet zozeer werd ingegeven door een praktische bekommernis voor het leven van de zuigeling :

"Des évêques aus psychanalystes, en passant par les médecins raisonnant sur la théorie des humeurs, la liste est longue de

55. J. GELIS, M. LAGET, M.-F. MOREL, Entrer dans la vie. Naissances et enfances dans la France traditionnelle, Parijs, 1978.

56. Ibidem, p. 123. 
tous ceux qui au cours des siècles ont voulu empêcher les mères de réchauffer leurs enfants. Cet interdit a certainement des racines bien plus culturelles que pratiques : certes, la réalité des enfants étouffés existe, mais de moins en moins précisément à mesure que se renforce l'interdit. Et si l'on observe les pratiques maternelles dans d'autres cultures, on s'aperçoit que lorsque les nourissons dorment presque toujours avec leurs parents, ils ne sont apparemment pas plus étouffés qu'ailleurs"s?

Deze nieuwe en interessante visie verdient zeker nader onderzoek, maar intussen kan men de kerkelijke verbodsbepalingen toch moeilijk herleiden tot een verkapt incestverbod ! Het klopt dat predikanten bij tijd en wijle hebben afgeraden dat kinderen van 6 jaar en ouder het bed of de slaapkamer van hun ouders of van het dienstpersoneel zouden delen. Het was ook niet toegelaten dat kinderen waarvan het geslacht verschilde samen in één bed sliepen ${ }^{58}$. Dat was onmiskenbaar bedoeld om kinderen te behoeden voor incestueuze of andere ongewenste sexuele ervaringen. Maar als de Kerk verbood dat volwassenen met heel jonge kinderen het bed zouden delen, had zij wel degelijk het verstikkingsgevaar op het oog, of nog het risico op een mogelijke fatale valpartij.

Heeft de Kerk deze risico's dan schromelijk overschat ? Kwamen fatale ongelukken wel zo dikwijls voor als kerkelijke documenten laten uitschijnen ? Deze vragen zijn gemakkelijker te stellen dan te

\section{Ibidem, p. 123-4.}

58. Zie by. P. Massemin, Sermoenen op de sondagen, dl.2, p. 307-8: "Den H. Franciscus de Sales(...), in zynen eersten brief, die hy geschreven heft na eene zekere weduwe, onder andere zedenlessen om haere kinderen wel, en godvrugtiglyk op te voeden, tragt jaer grootelyks in-te-drucken, dat zy hun alleen zoude doen slaepen : en is't dat zy haer dogterken by een ander wilt laeten slaepen, dat het zoodanige duegdzaeme vrouws-perzonen moesten zyn, dat zy zoo wel op hun, als op haer eigen zelve zoude mogen betrouwen :(..). Wat zoude die man Godts gezeid hebben, waer het zake dat hy wist, dat'er ouders gevonden worden, die knegtjes en meiskens van zes, zeven en meer jaeren in't het [sic] zelve bedde keggen, of een ander met hun in hun eigen bedde laeten slaepen? Men kan zkerlyk niet zeggen dat zy vry zyn van groote zonde : gelyk het ook t'eenemael gevaerlyk is, kinderen van die jaeren te laeten slaepen in hunne eigen slaepkamer, ten zy dat zy alle mogelyke voorzigtigheid gebruiken ; want zy moeten hun laeten voorstaen, dat ook de muizen ooren hebben". Massemin geeft o.m. een tamelijk recent en ophefmakend voorbeeld van een broer/zus-incestgeval uit Frankrijk. 
beantwoorden, omdat kerkelijke woordvoerders doorgaans geen toonbeelden zijn van accuraatheid en exactheid als zij het hebben over de frequentie van die ongevallen. Dat is één van de grote frustraties van de historicus die op dergelijke bronnen is aangewezen. Het wordt nog complexer als men bedenkt dat predikanten de hele zaak wellicht fel hebben opgeschroefd om de toebehoorders te brengen waar zij ze hebben wilden. Prosper Florisoone (?-1798) bv., regulier kanunnik van de abdij van Voormezele en sinds 1764 pastoor van Gyverinkhove ${ }^{59}$, riep uit : "Godt gave, dat'er by duyzend Moeders op deeze wyze niet pligtig waeren van eene Kindermoord" 60 , waarbij zowel het getal "duizend" als de term "kindermoord" (die geenszins voorbedachtheid impliceerde, zoals uit de context duidelijk blijkt) het dramatisch effect moesten maximaliseren. Anderen waren zo mogelijk nog vager en stelden gewoon dat dodelijke incidenten veel meer voorkwamen dan algemeen werd aangenomen. De Vloo verzekerde zijn publiek : "Dit ongeluk geschied al veel meer als gy $\mathrm{u}$ laet voorstaen ; zy gaen het langs straet niet uytbellen, die over dit ongeluk gedwongen zyn te draegen eene knaegende conscientie" ${ }^{61}$. Backx en Massemin lieten zich uit in dezelfde zin. Ook zij schrijven het feit dat de publieke opinie maar weinig weet had van concrete ongelukken toe aan de angstvallige discretie van ouders die zo'n tragisch voorval hadden meegemaakt. Verslype was trouwens de enige die op een directe manier een beroep deed op de persoonlijke ervaring van de aanwezigen : "Ik vreese wel, dat'er misschien hier wel tegenwoordig zyn, die daer van droeve voorbeelden weten, en misschien geproeft hebben"62. De Bijbel maakt in 1Kon. 3: 16-28 echter melding van een voorbeeld waarvan de bewijskracht in de ogen van de predikanten minstens even zwaar woog als alle eigentijdse ervaringen samen. Er werd dan

59. Enkele schaarse gegevens bij C.-F.-A. PIRON, Algemeen levensbeschryving der mannen en vrouwen van België, Mechelen, 1860, p. 121. FLORISOONE hield zich als amateur ook bezig met geneeskunde ; zie daarover : L.ELAUT, "Pastoor Florisoone van Gijverinckhove doet het met 'spouwen en douwen, met vryven en niezen', in : Biekorf 76 (1975-76), p. 35-44.

60. P. FLORISOONE, Nieuwe Vlaemsche sermoenen, dl. IV, Brugge (Joseph De Busscher), 1781, p. 57.

61. I.A. DE VLOO, Sermoenen, dl. V, p. 149.

62. J. VERSLYPE, Historie, dl. V/1, p. 434. 
ook dikwijls verwezen naar dit verhaal over een vrouw die haar kindje al slapende versmacht had, en het daarna verwisselde voor de levende baby van een huisgenote. Toen de moeder van de levende baby het bedrog ontdekte deed zij een beroep op koning Salomon, die zijn bekende salomonsoordeel velde ${ }^{63}$. Backx knoopte er deze praktische conclusie aan vast : "Het gene aen die Moeder overcomen is, cander aen meer over-comen" ${ }^{64}$. Of dat veel indruk maakte is lang niet zeker. Als de waarschuwingen van de clerus vaak op ongeloof stuitten, hield dat ongetwijfeld verband met het feit dat de beproefde ouders begrijpelijkerwijze zo weinig mogelijk ruchtbaarheid wensten te geven aan wat hen overkomen was. Vandaar dat de inspanningen van de Kerk er vooral op gericht waren om de gelovigen die meenden dat kinderversmachting een ingebeeld, verafgelegen gevaar was, ervan te overtuigen dat het wel degelijk om een reëel perikel ging. Backx pakte het als volgt aan :

"Noch men moet niet meynen, dat de ongevallen die daer uyt gevreest worden, soo selsaem zijn, dat dit maer ydele vreese soude zyn, ende maer een ingebelt oft immers maer een verre gelegen peryckel. Neen. ' $t$ Is een redelyke vreese, ende een peryckel dat sijn fondament heeft : ende die ongevallen, die daer van voortskomen, gebeuren misschien al dickwilder dan men meynt. Hoe licht en kan het niet gebeuren, dat Vader oft Moeder onbedachtelijck, oft in den slaep sigh om keerende die teere kinderkens eenigh hinder doen ?"65

Al bij al zijn we daarmee niet veel wijzer geworden over de reële omvang van het verschijnsel kinderversmachting. Mijn indruk is dat de uitspraken van de predikanten daarover met een flinke korrel zout moeten genomen worden. Het is zonneklaar dat de Kerk de toestand zwarter voorstelde dan ze in feite was, en wel omwille van het effect. Als je goed luistert en abstractie maakt van alle retorische franjes, stelden Backx en zijn collega's eigenlijk niet dat zulke ongelukken dikwijls voorkwamen, maar toch té dikwijls gebeurden.

63. J. MARCHANTIUS, p.189; R. BACKX, Vervolgh der sermoenen op de sondaegen van het jaer, dl.I, Antwerpen (Petrus Jouret), 1712, p. 142 en CXXV sermoonen, dl.II, p. 273 ; P. MASSEMIN, p. 304 ; I.A. DE VLOO, p. 181.

64. R. BACKX, CXXV sermoonen, dl.II, p. 273.

65. R. BACKX, Vervolgh, dl.I, p. 142. 
Of zoals Petrus Franciscus Valcke (1708-1787), de bekende pastoor van Rumbeke ${ }^{66}$ het uitdrukte : "Zy moet haer wagten van die kleyne Schaepen by haer in't bedde $t$ leggen, uyt vreeze van de zelve al slaepende te versmagten, het welk, eylaes! maer al te dikwils geschied"67. Daarbij moet men bedenken dat in de ogen van de Kerk elk sterfgeval er één te veel was, omdat het - mits de nodige voorzorgen van de ouders - kon en moest vermeden worden. Het leven van ieder menselijk wezen was voor haar dermate waardevol en onvervangbaar, dat het aan geen enkel risico - hoe klein ook mocht worden blootgesteld.

Vanuit die optiek is het niet verwonderlijk dat de Kerk het bij zich in bed nemen van zuigelingen meestal in absolute termen heeft veroordeeld. Benedicti scheen echter bereid om een uitzondering te maken voor moeders die afdoende veiligheidsmaatregelen troffen. Als het bed voldoende breed was, en als er tussen moeder en kind een soort afscheiding werd aangebracht, zodat beiden ver genoeg van elkaar verwijderd bleven, kon hij gedogen dat het kleintje mee in bed genomen werd. Benedicti stond met deze stellingname vrij geïsoleerd. De $17 \mathrm{e}$ - en $18 \mathrm{e}$-eeuwse Vlaamse predikanten duldden geen enkele afwijking van de algemene regel dat jonge kinderen en volwassenen niet samen in één bed mochten slapen. Met de omstandigheden waarin dat gebeurde, en met de beweegredenen van ouders en minnen werd totaal geen rekening gehouden. Alles wat zij te hunner verdediging aanvoerden werd prompt afgewezen en als loze uitvlucht gedoodverfd. Welke waren nu de motieven die de mensen aanhaalden om hun kroost bij zich in bed te nemen ? Hoe reageerden zij op de verwijten van de clerus ?

De motieven vallen in twee categorieën uiteen. De ene zou men eerder altruïstisch kunnen noemen, de andere egoïstisch. Het getuigt zeker van liefde en bezorgdheid voor het welzijn van het kindje als zij het bij zich in bed namen om het te beschermen tegen de koude, of uit medelijden, omdat het onophoudelijk huilde en kennelijk

66. Cf. B. JANSSENS DE BISTHOVEN, "Petrus Franciscus Valcke, 1708-1787, pastoor van Rumbeke en deken van Roeselare", in : Handelingen van het Genootschap voor Geschiedenis gesticht onder de benaming 'Société d'Emulation' te Brugge, 161 (1984), p. 137-47.

67. P.F. VALCKE, Sermoenen op de sondagen en de feestdagen, dl. VI, Brugge (Joseph De Busscher), 1786, p. 31. 
wilde getroost worden. Volgens Backx verantwoordden ouders zich o.m. door op te werpen "datse dat moeten doen, om dat de kinderen geen koude en souden lyden, oft omse snachts te suygen te geven, om datse den heelen nacht niet en souden kryten" ${ }^{68}$. Florisoone valt scherp uit tegen "de Moeders, de welke uyt een zinneloos medelyden, hunne Kinders, op dat zy niet zouden schreyen, by hun in't bedde leggen" ${ }^{\prime}$. Backx weet ons verder te melden dat sommige ouders hun kindje zozeer beminden, dat zij het ook's nachts bij zich wilden hebben. Hij trekt een parallel tussen die in zijn ogen overdreven en ongezonde ouderliefde en de apenliefde, waarvan men geloofde dat ze zo sterk was dat apen hun jongen al omhelzende soms versmachtten. Hij kon geen begrip opbrengen voor "Ouders, de welcke de jonge en teere kinderkens al te vroeg by hun in't bedde leggen somtyts uyt eene sotte liefde, gelijck aen de liefde van de Simmen die haere jonckskens soo lief hebben, dat sy die dickmaels al omhelsende versmooren" ". Er zij nogmaals op gewezen dat deze altruïstische motieven, die bij een aantal ouders duidelijk aanwezig waren, in het geheel niet te rijmen vallen met de zienswijze van Chris Vandenbroeke.

De belangrijkste drijfveer om het kerkelijk verbod te trotseren, blijkt toch de bekommernis te zijn geweest om de nog tere en

68. R. BACKX, Vervolgh, dl.I, p. 143. Zie ook J. MARCHANTIUS, p. 181, wiens Hortus Pastorum op Backx' werktafel lag toen hij dit sermoen redigeerde.

69. P. FLORISOONE, p. 56.

70. R. BACKX, $C X X V$, dl.II, p. 273. Het beeld van de aap die zijn jongen ongewild doodrukt tijdens een liefdevolle omhelzing werd trouwens vaker gebruikt op te waarschuwen tegen verwennerij en al te tedere gevoelens jegens kinderen. Het thema was ook vrij populair in de emblemataliteratuur van de Nieuwe Tijd. Zie bv. J. CAMERARIUS, Symbolorum \& emblematum ex animalibus quadrupedibus desumtorum centuria, Nürberg, 1595 (facsimile-uitgave bezorgt door W. Harms en U.-B. Kuechen, Graz, 1986), f. 85. Onder de afbeelding staat volgende tekst te lezen : "Est cum \& amare nocet. Suffocat simia amando simiolum. Exemplum hoc o fugitote patres". Zie ook : J. VAN DEN VONDEL, Vorstelijke warande der dieren, Amsterdam, 1617 (fascimile-uitgave Soest, 1974, met een inleiging van J. Becker), f. 5. De opvatting dat apen hun jongen soms al omhelzende verstikken is afkomstig van de Romeinse auteur Plinius (de Oudere), Cf.F. Pinicelli, Mundus symbolicus, Keulen, 1687 (fascimile-editie bezorgd en ingeleid door D. Donat, Hildesheim-New York, 1979), p. 421 :"Plinius [Plin. l.8. c. 54] de Simiis refert ; Simiarum generi praecipua erga foetum affectio. Et paulo post; itaque magna ex parte complectendo necant : Unde catulum suum amplexu suffocans, epigraphen tenet. COMPLECTENDO NECAT." 
kwetsbare zuigelingen goed warm te houden. Een enkele keer kon een geestelijke daar ook zijn goedkeuring aan hechten. Klaus Arnold citeert een passage uit een $14^{\circ}$-eeuwse Summa van de dominicaan Berthold von Freiburg ${ }^{71}$ waarin ouders die kinderen bij zich in bed namen om ze tegen koude en ongedierte te beschermen, onschuldig werden geacht :

"Ist das die elltern ire kind zuo in nemen an daz bethe von frost und keltin wegen, oder fürchten ir von den tieren oder vor den würmen, und sterben die kind bey in in den bedt, so sy schlafen und werden ertrucket, so seind die elltern nicht schuldig an dem tod"72.

Heel anders beoordeelde deze Berthold von Freiburg mensen die het deden uit overdreven liefde ("unordentlicher lieb"), uit gemakzucht of wanneer ze in dronken toestand waren. Hij hield m.a.w. rekening met de motieven van de ouders om de schuldvraag te beoordelen. Bij ons in de Nieuwe Tijd deed men dat niet, en zeker niet op de preekstoel. Backx veegde de argumenten van de ouders met één enkele zin van tafel : "'t Waer beter (...) dat en de Ouders en de kinderen des nachts wat ongemack leden, dan haer selven en de kinderen in soo-danigh peryckel te stellen" ${ }^{\text {"3 }}$. Florisoone redeneerde in dezelfde zin : "De goede en fraeye Ouders stellen hunne Kinders dan noyt in eenig gevaer, waer in zy hun leven zouden konnen verliezen ; maer zy hebben de zelve liever te hooren weenen, als zy hun anders niet helpen konnen"74.

Uiteraard was de Kerk helemaal niet te spreken over ouders die eerder hun eigen gemak en comfort op het oog hadden. Veel vrouwen zagen er tegen op om 's nachts herhaaldelijk te moeten opstaan om een huilende baby te sussen om hem de borst te geven, en namen het kleintje daarom mee in bed. Dat is wat Benedicti aan moeders en minnen verweet. De Vloo erkent dat het niet meevalt om 's nachts voordurend heen en weer te draven tussen de eigen slaapstede en het wiegje van de baby, maar dat zijn nu eenmaal

71. Cf.E. FILTHAUT, "Berthold von Freiburg", in : Lexicon für Theologie und Kirche II (1958), k. 266.

72. Geciteerd door K. ARNOLD, Kind und Gesellschaft, p. 49.

73. R. BACKX, Vervolgh, dl.I, p. 143.

74. P. FLORISOONE, p. 57. 
ongemakken die inherent zijn aan het moederschap. Hij meende bovendien dat vele moeders die last alleen aan zichzelf te wijten hadden, omdat ze het kind van jongsaf aan hadden verwend door het altijd bij het minste teken van onbehagen te gaan troosten :

"Maer zonder dit, zeggen ander [Moeders], geen ogenblik kan ik rusten. 't Is een zwaer last, ik beken het, maer een last 't welk gy vrywilliglyk hebt aengenomen ; en een last, 't welk gy zelfs gevoed hebt, met van eersten af, uw Kind niet anders te gewennen"'s

Massemin deed er nog een schepje bovenop en beschuldigde hen ronduit van gemakzucht :

"Maer, zegt een ander, myn kind is te lastig, en te moeielyk, het wilt anderzins niet zwygen, en ik kan niet eene ooge luiken : ik kan niet gedeuriglyk opstaen om de borst te geven, enz. Maer vrouwken, waerom zyt gy getrouwt ? Is't om u gemak te hebben, en uwe lusten te voldoen ? Wilt gy moeder zyn zonder last, en moeielykheid ? Gy zyt grootelyks bedrogen. Als gy de lasten van het huwelyk niet wilde dragen, gy moest $\mathrm{u}$ daer toe niet begeven hebben : het is dan uwe pligt, het is uwe verbintenisse voor uw kind te waken, op te staen, om het de borst te geven, als't noodzakelyk is. Ziet wat eenen hond doet voor zyne jongen, als zy schreeuwen, hy zal alles verlaeten, al waer't de beste brocke vlees, om te gaen zien, wat'er met hun hapert : de stomme beesten maken u beschaemt, die om uwe vaddigheid en luiheid te voeden, uw kind stelt in gevaer van het leven"76.

Ook Backx verweet de moeders "luiaerdye en gemackelijkheyd"" Het is ontegensprekelijk zo dat de meeste mensen op hun nachtrust gesteld waren. Maar om nu te stellen dat ze erger waren dan de beesten, zoals Massemin zich in het vuur van zijn betoog liet ontvallen, dat gaat toch te ver ! Mogen wij de beschuldiging van kerkelijke zijde, dat ouders meer waarde hechtten aan hun comfort dan aan het leven van hun kroost, wel zonder meer als terecht

75. I.A. DE VLOO, p. 150.

76. P. MASSEMIN, p. 305.

77. R. BACKX, CXXV sermoonen, dl.II, p. 273.

78. P. MASSEMIN, p. 305. 
beschouwen ? Als een historicus kritiekloos alles zou geloven wat moralisten en predikanten aan hun tijdsgenoten verweten hebben, zou hij wel tot de conclusie moeten komen dat Vlaanderen in het Ancien Régime hoofdzakelijk bevolkt werd door losbandige, perverse en ontaarde lieden... Het is veeleer zo dat de gewone man, i.t.t. de kerkelijke gezagdragers, de risico's van het bij zich in bed nemen van kinderen bijzonder klein of onbestaande achtte. De predikanten benadrukten zelf dat men het gevaar niet zag, tot het te laat was en men gedwongen was het te betreuren. Massemin had ergens opgevangen dat ouders zich er op beroemden dat zij altijd hun kleintjes bij zich in bed namen en nog nooit iets hadden voorgehad : "Iemant zal zeggen : ik hebbe dit zoo dikwils gedaen, Godt lof, het heeft altyd wel gegaen." En hij repliceerde : "Gy hebt daerom niet laeten grootelyks te zondigen, om dat gy $\mathrm{u}$ ten minste gestelt hebt in een alderzwaerste perykel, en dit zelve te doen is eene groote sonde" $"$.

Anderen betrouwden op hun voorzichtigheid, maar De Vloo moest daarmee hartelijk lachen :

"Maer ik ben voorzigtig, zeggen zommige Moeders, en daer en is geen perykel. Hoe, gy zyt voorzigtig, zelfs als gy slaept ? Wonderbaere voorzigtigheyd !... den H.Augustinus lacht met de Joden, die de slaepende Soldaeten voor getuygen namen, dat het Lichaem van den Heer, dewyl zy sliepen, van de Discipelen was gestolen ; met gelyke reden mogen wy lagchen met de voorzigtiheyd van de slaepende Moeders. Inderdaed de Vrouw, die ten tyde van Salomon slaepende, haer Kind had doodgelegen, peysde zonder twyffel zeer voorzigtig te zyn, want zy beminde haer Kind ; en nogtans met al dit ; met al haer slaepende voorzigtigheyd, zy heeft haer Kind doodgelegen : dormiens quippe oppressit eum. En zy heeft te saemen een exempel naergelaeten aen alle Moeders, 't welk doet zien, wat uyt zulke voorzigtigheyd kan volgen"?

Vrijwel iedereen beklemtoonde dat men tijdens de slaap geen controle meer heeft over zijn bewegingen. De kans was ook reëel, dat men het gehuil of het geworstel van de baby die dreigde te stikken niet zou merken. Florisoone wendde al zijn retorisch talent aan om de moeders daarvan te overtuigen :

79. I.A. DE VLOO, p. 149-50. 
"Het is tegen u dan, verwaende Moeders, dat ik hier uytvalle, met $u$ over uwe uytzinnigheyd te bestraffen, door dien dat gy uwe Kinders by $\mathrm{u}$ in uw bedde leggende, om hun geschreeuw te stelpen, u dikwils in perykel stelt van hun in uwen slaep te versmagten ; want als die teere kinderen aen uwe zyde liggen, zyt gy verzekert, dat gy, vermoeyt van den arbeyd, en door den vaek overvallen, $\mathrm{u}$ in uwen slaep niet zult keeren en omwenden, en alzoo uw Kind niet zult perssen en versmagten ? Ik neeme dat uw onnoozel Schaepjen, door de zwaerheyd van uw lichaem zig geperst voelende, nog eenig geschrey zal uytwerpen, door de pyne die het voelt : zyt gy zeker, dat gy zyn geklag hooren zult, byzonderlyk als gy, door de onruste en vermoeytheyd, in eenen vaste slaep ligt? En ten anderen, kan't niet gebeuren, dat $u$ Kind leeger in 't bedde zinkende, gy synen mond stopt, en alzoo, syn geschrey belettende, 't zelve versmagt ? Godt gave, dat'er by duyzend Moeders op deeze wyze niet pligtig waeren van eene Kinder-moord. Ach ! zinnelooze en wreede Moeders, die onder het voorgeeven van uwe Kinders in het geween te troosten, hun naar 't ander leven zend. Gy zult misschien zeggen, dat gy gewoon zyt altyd stille in uw bedde te liggen ; maer zyt gy zeker, dat gy altyd stille zult blyven liggen? Ten is dan niet zonder reden, dat de zwaere doodelyke zonde, die door de vesmagting van een Kind bedreeven word, in zommige Bisdommen, van alle Priesters niet kan vergeeven worden ; want men kan geenen grooten schroom genoeg aan de Moeders indrukken, op dat zy zig zouden myden van hunne Kinders in gevaer des doods te stellen, met de zelve by hun in't bedde te neemen"so.

Men was niet alleen bewust van de gevaren - en de vraag blijft of de Kerk die niet schromelijk heeft overschat-, maar in veel gevallen hadden arme mensen naar eigen zeggen weinig keuze. Hun bescheiden bestaansmiddelen lieten hen eenvoudigweg niet toe om voor een apart wiegje te zorgen, of zij waren te eng behuisd om voor de baby een afzonderlijke slaapplaats te reserveren. Terwijl Benedicti nog geneigd was om de zaak in die omstandigheden over te laten aan het geweten van de betrokkenen, aanvaardde men bij ons ook armoede niet als excuus. Marchantius schreef :

80. P. FLORISOONE, p. 56-7. 
"Nec facile ea in re admittitur excusatio matrum, ob paupertatem se excusantium, quod eis locus commodus et lectus separatus non suppetat, in quo collocare possint infantes $;(\ldots)$ Imo convenit pastores quandoque improvide infantes saepe periculo exponit" ${ }^{81}$

Onder meer Backx heeft deze raad ter harte genomen, en preekte dat "d'excusie oft ontschuldinge van sommige, die seggen datse dat uyt armoede doen, als gen comoditeyt, gelegenheyd, oft middel hebbende, om de kinderen in een wieghskens [sic] oft beddeken appaert te leggen" niet "ontfanckbaer" is ${ }^{82}$. Ik kan mij nochtans levendig voorstellen dat dit voor armere bevolkingsgroepen inderdaad een vrijwel onoverkomelijk probleem was. Volgens de auteurs van Entrer dans la vie ontbraken wiegen tot diep in de $18^{\mathrm{e}}$ eeuw in de woningen van de allerarmsten. Zij hadden er het geld niet voor, en wat zeker een even grote rol speelde : ze zagen er ook niet nut niet van in. In huishoudens waar men wel over een wieg beschikte lijkt die vooral overdag dienst te hebben gedaan ${ }^{83}$. Aangezien Marchantius en Backx, die de auteur van de Hortus pastorum gewoon napraat, de enigen zijn die aangeven dat armoede soms als excuus werd ingeroepen, mogen we aannemen dat de materiële infrastructuur in onze gewesten niet de voornaamste hinderpaal geweest is voor de naleving van de kerkelijke voorschriften. Als de Kerk op dit vlak zo weinig bereikt heeft, was dat veel meer een kwestie van mentaliteit en gewoonte dan van geld of plaatsgebrek. Massemin verzuchtte in 1718 :

"Dog dat alles is zoo veel te droeviger, als'er in dergelyke zaken gy vele min werk gemaekt word : vele zyn hier in wel gerust, zy peyzen niet eens, of zy willen niet eens peyzen, dat zy zondigen, en vervolgens zy beschuldigen zig hier over niet, zy hebben geene de minste droefheid, en alzoo en beteren zy hun niet" $"$.

De Vloo hoopte - tegen beter weten in ? - op een positiever resultaat :

81. J. MARCHANTIUS, p. 180-1.

82. R. BACKX, Vervolgh, dl.I, p. 143.

83. J. GELIS, M. LAGET, M.-F. MOREL, p. 124.

84. P. MASSEMIN, p. 305-6. 
"Uyt alle dit, 't welk ik op deze Stoffe, de welke zoo raer van den Stoel der Waerheyd word verhandelt, voor alsnu gezeyd heb, wat vrugt, wat voordeel mag ik verwagten ? Gy zult misschien peyzen, alles vrugteloos ; neen, myne goede Catholyke, ik betrouwe door de godlyke Gratie, hier uyt groote vrugt, veel geestelyke Winste. (...) Ik houde my verzekert, dat alle welpeyzende Moeders voortaen liever alle moeyte, onruste en slaevernye zullen verdraegen, als maer eens hun onnoozel Kind met hun te nemen in de ruste, op dat zy het leven niet in gevaer stellen van hun Kind, 't welk zy niet, maer Godt zelve hem [sic] heeft gegeven" 85 .

Terugblikkend meen ik Vandenbroekes ideë̈n over het bij zich

Terugblikkend meen ik Vandenbroekes ideeën over het bij zich in bed nemen van kinderen te moeten verwerpen. Ze missen immers voldoende grond als men de kerkelijke documentatie over dit onderwerp in de Nieuwe Tijd van naderbij bekijkt. Een krasse uitspraak als zou opzettelijke maar gecamoufleerde kindermoord tot in de $18^{\circ}$ eeuw een courant aangewende "malthusiaanse" strategie geweest zijn, vereist m.i. solider bewijsmateriaal dan waarmee Vandenbroeke voor de dag komt. De actie van de Kerk was immers niet gericht tegen potentiële kindermoordenaars, maar tegen een oeroude gewoonte die zij uiterst gevaarlijk achtte. Geen enkele kerkelijke woordvoerder beschuldigde zijn tijdgenoten van kwaad opzet of van het ensceneren van zogezegde ongelukken om aan rechtsvervolging te ontsnappen. Dit argumentum e silentio weegt des te zwaarder als men weet dat predikanten allesbehalve zuinig omsprongen met harde verwijten en insinuaties. Als Florisoone in dit verband het woord "kindermoord" in de mond nam, impliceert dat niet dat hij de ouders voorbedachtheid aanwreef. Hij wou gewoon door deze krasse taal de overtreders van het kerkelijk verbod afschrikken en culpabiliseren. In dezelfde zin sprak men ook van "zelfmoordenaars" i.v.m. lieden die zich aan de drank te buiten gingen, of een losbandig leven leiden op sexueel vlak. Zo wierp men immers "vrijwillig" zijn gezondheid in de weegschaal en verkortte men zijn leven...

De waarschuwingen en dreigementen van de predikanten waren

85. I.A. DE VLOO, p. 156. 
gericht tot de ouders in het algemeen en de moeders in het bijzonder. Soms werd ook de min ter verantwoording geroepen. Dat de vader eerder uitzonderlijk ter sprake komt hoeft ons niet te verwonderen, aangezien de zorg voor het kleine kind van oudsher beschouwd werd als een typisch vrouwelijke aangelegenheid. Wellicht sliepen de zuigelingen ook niet tussen de ouders, maar tussen de moeder en de rand van het bed. Er wordt immers gewag gemaakt van kleintjes die uit het bed getuimeld zijn. Het ziet er naar uit dat de Kerk er niet in geslaagd is de gewoonte van het bij zich in bed nemen van zuigelingen uit te roeien. Men scheen de risico's te minimaliseren, en velen hadden zo hun eigen redenen om er ondanks de kerkelijke sensibiliseringscampagne mee door te gaan. Men deed het uit liefde en bezorgdheid voor het kind, uit gemakzucht, of om het neutraler te stellen, omdat men prijs stelde op een ongestoorde nachtrust, of nog uit bittere armoede. Fatale ongelukken kwamen wellicht minder vaak voor dan men op het eerste gezicht uit de kerkelijke bronnen zou geneigd zijn te geloven. De Vloo liet trouwens verstaan dat het thema van het bij zich in bed nemen van kinderen op de kansel eerder uitzonderlijk aan de orde was. Samen met het feit dat deze zonde in Brugge, Ieper, Gent, Antwerpen en Mechelen niet voorbehouden was, versterkt dit alleen maar ons vermoeden dat kinderversmachting door de hiërarchie bij ons niet als een eersterangsprobleem werd aangevoeld. Dit i.t.t. vele Franse bisdommen, waar men soms drastische maatregelen trof om de kwaal in de dijken, volgens Flandrin vanaf het einde van de $17^{\mathrm{c}}$ eeuw met een zeker succes. ${ }^{85}$ bis

85bis Voor wat Frankrijk betreft signaleren we ook het bestaan van een onuitgegeven "mémoire de maîtrise" waarvan het onderwerp gesuggereerd werd door J.-L. Flandrin : J. BENTOLILA, La prévention et la répression de l'infanticide dans les statuts synodaux, (Mém. maîtrise, Paris 1, 1972). Een beknopte synthese van deze studie vindt men in J. DELUMEAU, (ed.), La mort des pays de cocagne. Comportements collectifs de la Renaissance à l'âge classique, (Publications de la Sorbonne. Série "Etudes", tome 12), Parijs, 1976, p. 137-144. In 120 van de 295 bestudeerde statuts synodaux uit de $16^{c}-18^{e}$ eeuw kwam kinderversmachting (oppression d'enfant) ter sprake. (Ter vergelijking : in de Mechelse kerkprovincie werd daarover in diocesane statuten met geen woord gerept.) Twaalf dergelijke passages worden bij Delumeau in extenso geciteerd. Het zou ons te ver leiden om de aldaar voorgestelde resultaten van Bentolila's onderzoek hier samen te vatten. De laatste alinea van deze synthese willen we $\mathrm{u}$ echter niet onthouden : "Des analyses conduites par Jeannine Bentolila, il ressort donc que la plupart des suffocations d'enfants en bas âge devaient être le résultat de la négligence. Une preuve supplémentaire nous est donnée par le fait que les admonestations de l'Eglise s'adressent notamment aux nourrices. Or, celles-ci n'avaient pas intérêt à voir mourir les enfants qui leur étaient confiès contre 
$\mathrm{Nu}$ naar ik hoop is aangetoond dat onze $17^{\mathrm{e}}$ - en $18^{\mathrm{c}}$-eeuwse voorouders niet de barbaarse kindermoordenaars waren zoals voorgesteld door Vandenbroeke, moeten wij ons afvragen of ze toch niet erg onverschillig reageerden op de kerkelijke alarmkreten. Uiteindelijk waren die toch alleen maar bedoeld om het prille en kwetsbare leven van zuigelingen te beschermen. Verkoos men m.a.w. het risico te lopen van baby's te verstikken, liever dan 's nachts eens uit het warme bed te stappen om het kleintje de borst te geven of te gaan zien wat ermee scheelde ? Deze voorstelling van zaken past perfect in het kader van de overwegend pessimistische visie van veel gezinshistorici op de affectieve relatie tussen ouders en kinderen in vorige eeuwen ${ }^{86}$. Ook de predikanten stelden het zo voor, maar de ouders van het Ancien Régime hebben het wellicht niet zo ervaren. Eigenlijk zou je ook anno 1988 kunnen opperen dat ouders die hun kinderen in het drukke stadsverkeer alleen laten naar school gaan, onverantwoorde risico's nemen. Ik wed dat heelwat ouders zouden steigeren als men hen zou onder de neus wrijven dat zij liever het risico lopen dat hun kind in een ernstig ongeval betrokken raakt, dan dat zij zich de moeite getroosten om het zelf naar school te begeleiden ${ }^{87} \ldots$ Het is vrijwel zeker dat onze voorouders er stellig van overtuigd waren dat hun baby veilig was bij hen in bed. Als er iets misliep, zouden zij het wel merken. Volgens hen zagen predikanten en biechtvaders spoken... Wanneer het dan toch verkeerd uitdraaide - en we zullen wel nooit exact te weten komen hoe vaak dat gebeurde - werd het ongeluk volgens Marchantius met groot misbaar beweend.

rémunération. C'est donc à "une manière de vivre" que l'Eglise s'est attaquée : d'où la difficulté de se faire entendre, et la tenacité des résistances passives. Mais l'attitude des autorités ecclésiastiques a peut-être traduit à sa manière la montée du sentiment de l'enfance et de l'attention à l'enfant à l'étage le plus élevé de la société d'Ancien Régime." (p. 144.)

86. Op basis van tientallen dagboeken en autobiografieën uit de Angelsaksische wereld heeft de Engelse historica Linda Pollock dit paradigma van de gezinsgeschiedenis ernstig in vraag gesteld : L.A. Pollock, Forgotten children. Parent-child relations from 1500 to 1900 , Cambridge, 1983.

87. Met harde cijfers over kindermoord en jonge verkeersslachtoffers uit 1977 voor de Bondsrepubliek stelt Klaus Arnold zich vragen over de "kindervriendelije" mentaliteit van de late $20 \mathrm{e}$ eeuw, die zelfgenoegzame historici zo graag laten contrasteren met het verleden. K. ARNOLD, Kind und Gesellschaft, p. 43 : "Zu verlockend war es, der dunklen Vergangenheit eine kinderfreundliche Gegenwart entgegenzusetzen (...)". 